\title{
The Influence of Promotion and Distribution Accuracy on Consumer Purchase Interest in PT. Enzym Bioteknologi Internusa
}

\author{
Achmad Rozi \\ Sekolah Tinggi Ilmu Ekonomi Prima Graha Serang-Banten \\ E-mail: enggus.ahmad@gmail.com
}

(Received: December-2017; Reviewed: January-2018; Accepted: February-2018;

Avalaibel Online: February-2018; Published: March-2018)

(7) (5) This is an open access article distributed under the Creative Commons Attribution License CC-BY-NC-4.0 (02018 by author (https://creativecommons.org/licenses/by-nc/4.0/)

\begin{abstract}
The implementation of promotional activities carried out by the company includes advertising, sales promotion, personal sales, and publicity. This study aims to determine the effect of promotion and accuracy of distribution of consumer buying interest at PT. Enzym Biotechnology Internusa. The method used was explanatory research with a sample of 96 respondents. The analysis technique uses statistical analysis with regression testing, correlation, determination and hypothesis testing. The results of this study have a significant influence on consumer buying interest of $41.1 \%$, hypothesis testing obtained significance $0,000<0.05$. The accuracy of the distribution has a significant effect on consumer buying interest by $39.1 \%$, the hypothesis test obtained a significance of $0,000<0.05$. Promotion and accuracy of distribution simultaneously have a significant effect on consumer buying interest of $50.2 \%$, the hypothesis test obtained significance of $0,000<0.05$.
\end{abstract}

Keywords: Promotion, distribution accuracy, consumer buying interest.

\section{INTRODUCTION}

Nowadays product competition is increasingly crowded, in addition to the number of companies engaged in the same field, making competition more stringent, each company also has a variety of products with the same type and has almost similar characteristics, with such conditions so that competition will be even more complex. There are so many challenges that must be faced by a product in order to win the market and then be able to increase sales, still exist and succeed in the market and still maintain loyal customers even to fight over new customers, therefore the company must think of ways how to maintain and introduce its products (Peter \& Olson, 2014; Schiffman \& Kanuk, 2008; Sumarwan, 2014; Sutisna, 2003).

Personal care products are toothpaste products with the emergence of variant oral care or toothpaste from the same brand, so many manufacturers compete from the lowest and highest prices with a variety of claims of excellence owned by each product in order to attract interest 
by potential customers. The personal care products themselves consist of mouthwash, toothbrushes, toothpaste. Of the several types of products, which are quite potential are dental and oral care products or products (oral care) such as toothpaste, toothbrushes, and mouthwash. In the competition between companies in Indonesia, it is increasingly apparent as we can see in television advertisements, catalogs in supermarkets and many other places. This encourages PT. Enzym Biotechnology Internusa as the producer of Enzyme toothpaste carries out promotion and distribution activities, especially the competition between companies that produce the same or similar products in capturing markets. The problem faced by entrepreneurs now is not only how to improve their production results, but more important is how to sell the goods produced. The decision expected by the producer, whether the message conveyed through its promotion has been able to reach the planned market or not. If it has been reached, it means reflecting the success of its promotion and of course it can increase consumer demand (Angipora, 2002; Kotler \& Keller, 2009; Lovelock, Wirtz, 2013; Swastha, Basu, 2014; Tulasi, 2012).

Promotion is one of the marketing mix that is important in marketing and also as a way to provide information to the public about the goods or mass-produced by a company. The promotion also means activities that communicate the superiority of the product and persuade the target to buy it, therefore the company must always establish the best possible communication with consumers and prospective customers through promotional activities. The implementation of promotional activities carried out by the company includes advertising, sales promotion, personal sales, and publicity. This promotional activity is known as a promotional mix. According to (Kotler dan Amstrong, 2008), promotion is an activity that communicates the benefits of a product and persuades consumers to buy the product. In addition to the promotion factor, there is the no less important thing, namely distribution channel, where the distribution channel plays a very important role in order to meet the demands of consumers who can be on time and available at any time (Assauri, 2011; Fandy Tjiptono dan Gregorius Chandra, 2008; Maruf, 2006; Morissan, 2015). The function of distribution channels from goods to producers. Distribution channels that regulate matters in time, place and ownership that take goods and services from those who use them (Alma, 2011; Lupiyoadi, 2011, 2013; Shinta, 2011; Sutisna, 2003). This distribution channel is also a concern of PT. Enzym Bioteknilogi Internusa in maintaining its products to remain available in all stores that are sales branches. Delay will lead to the consequence that consumer loyalty to the brand of its product decreases, which is caused by the number of perfect substitute products that have quality and prices that are competitive with the company's products concerned. If this often happens in a company, then consumer loyalty to certain product brands will eventually decrease and the possibility of consumers can switch to other product brands. This event is logical and can be accepted by the ratio, especially for consumer goods that are needed in a fast time, so that consumers are better off consuming other available products rather than having to waste time searching for the product they are looking for. Given this reality, then how important is the right choice of the distribution channel problem used by a company. Because if the distribution is late it will affect the sales of the product itself.

\section{METHOD}

The type of research used is associative, where the aim is to find out the relationship between variables. The population in this study amounted to 96 respondents PT. Enzym Bioteknologi Internusa. The sampling technique in this study is saturated sampling, where all members of the population are sampled. Thus the sample in this study amounted to 96 respondents. In analyzing the data used the instrument test, classical assumption test, regression, coefficient of determination and hypothesis testing. 


\section{RESULT AND DISCUSSION}

PT. Enzym Bioteknologi Internusa as a toothpaste producer produces products that are the main products and also carries out promotional activities to introduce its products to consumers in the hope that consumers will use their products. The importance of determining the right promotional activities is expected to reduce costs as low as possible and be able to use several promotional alternatives in order to introduce products and their benefits to the community in addition to increasing sales in achieving maximum profit.

\section{Descriptive Analysis}

This test used to determine the highest minimum and maximum scores, ratting scores and standard deviations of each variable. The results are as follows:

Table 1

Descriptive Statistics Analysis Results

Descriptive Statistics

\begin{tabular}{lr|r|r|r|r}
\hline & N & Minimum & Maximum & Mean & \multicolumn{1}{c}{ Std. Deviation } \\
\hline Promotion (X1) & 96 & 32 & 48 & 38.32 & 3.824 \\
\hline Distribution Accuracy (X2) & 96 & 30 & 45 & 38.31 & 3.717 \\
\hline Increased Sales (Y) & 96 & 32 & 46 & 39.14 & 3.532 \\
\hline Valid N (listwise) & 96 & & & & \\
\hline
\end{tabular}

Promotion obtained a minimum variance of 32 and a maximum variance of 48 with a rating score of 38.32 with a standard deviation of 3.824. The accuracy of the distribution obtained a minimum variance of 30 and a maximum variance of 45 with a rating score of 38.31 with a standard deviation of 3,717. Consumer buying interest obtained a minimum variance of 32 and a maximum variance of 46 with a rating score of 39.14 with a standard deviation of 3.532

\section{Regression Multiple Analysis}

This regression test is intended to determine changes in the dependent variable if the independent variable changes. The test results are as follows:

Table 2.

Multiple Regression Testing Results

Coefficients $^{\mathrm{a}}$

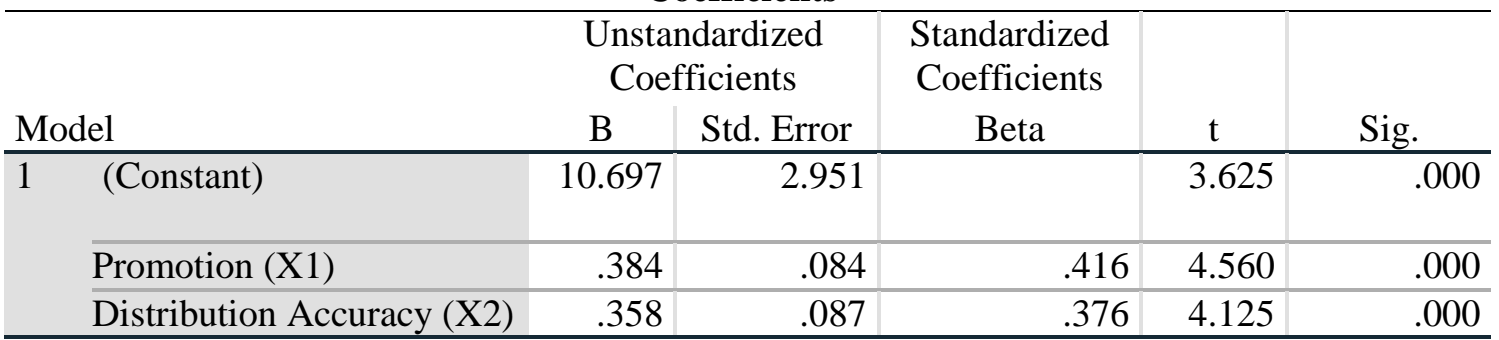

a. Dependent Variable: Increased Sales (Y)

Based on the test results in the table 2, the regression equation $\mathrm{Y}=10.697+0.384 \mathrm{X} 1+$ $0.358 \times 2$ is obtained. A constant of 10.697 means that if there is no promotion and accuracy of 
distribution, then there is a value of consumer buying interest of 10.697 points. The promotion regression coefficient of 0.384 , this number is positive, meaning that every time there is an increase in promotion of 0.384 , consumer buying interest will also increase by 0.384 points. The distribution accuracy regression coefficient is 0.358 , this number is positive, meaning that every time there is an increase in distribution accuracy by 0.358 , consumer buying interest will also increase by 0.358 points.

\section{Correlation Coefficient Analysis}

Correlation coefficient analysis is intended to determine the degree of relationship strength of the independent variables on the dependent variable either partially or simultaneously. The test results are as follows:

Table 3.

Test Results Correlation Coefficient Promotion of Consumer Buying Interest.

\begin{tabular}{llr|r} 
& \multicolumn{1}{c}{ Correlations $^{\mathbf{b}}$} & $\begin{array}{c}\text { Promotion } \\
(\mathrm{X} 1)\end{array}$ & $\begin{array}{c}\text { Increased Sales } \\
(\mathrm{Y})\end{array}$ \\
\hline Promotion (X1) & Pearson Correlation & 1 & $.641^{* *}$ \\
\cline { 2 - 4 } & Sig. (2-tailed) & & .000 \\
\hline Increased Sales (Y) & Pearson Correlation & $.641^{* *}$ & 1 \\
& Sig. (2-tailed) & .000 & \\
\cline { 2 - 5 } & & & \\
\hline
\end{tabular}

**. Correlation is significant at the 0.01 level (2-tailed).

b. Listwise $\mathrm{N}=96$

Based on the test results obtained a correlation value of 0.641 means that promotion has a strong relationship with consumer buying interest.

Table 4.

Correlation Coefficient Testing Results Distribution Accuracy on Consumer Buying Interest.

Correlations $^{\mathbf{b}}$

\begin{tabular}{llr|r}
\hline & & $\begin{array}{r}\text { Distribution } \\
\text { Accuracy (X2) }\end{array}$ & $\begin{array}{r}\text { Increased Sales } \\
\text { (Y) }\end{array}$ \\
\hline Distribution Accuracy (X2) & Pearson Correlation & 1 & $.625^{* *}$ \\
& Sig. (2-tailed) & & .000 \\
\hline Increased Sales (Y) & Pearson Correlation & $.625^{* *}$ & 1 \\
\cline { 2 - 4 } & Sig. (2-tailed) & .000 & \\
\hline
\end{tabular}

**. Correlation is significant at the 0.01 level (2-tailed).

b. Listwise $\mathrm{N}=96$

Based on the test results obtained a correlation value of 0.625 means that the accuracy of the distribution has a strong relationship with consumer buying interest. 
Table 5.

Test Results Correlation Coefficient Promotion and Distribution Accuracy Simultaneously on Consumer Buying Interest.

Model Summary

\begin{tabular}{lr|rrr}
\hline Model & \multicolumn{2}{c|}{$\begin{array}{c}\text { Adjusted R } \\
\text { Square }\end{array}$} & \multicolumn{2}{c}{$\begin{array}{c}\text { Std. Error of the } \\
\text { Estimate }\end{array}$} \\
\hline 1 & R Square & .492 & 2.519 \\
\hline a. Predictors: (Constant), Distribution Accuracy (X2), Promotion (X1)
\end{tabular}

Based on the test results obtained a correlation value of 0.709 means that promotion and accuracy of distribution simultaneously have a strong relationship to consumer buying interest.

\section{Analysis of the Coefficient of Determination}

Analysis of the coefficient of determination is intended to determine the percentage of influence of the independent variable on the dependent variable either partially or simultaneously. The test results are as follows:

Table 6.

Test Results for Promotion Determination Coefficient on Consumer Buying Interest.

Model Summary

\begin{tabular}{|c|c|c|c|c|}
\hline Model & $\mathrm{R}$ & R Square & $\begin{array}{c}\text { Adjusted R } \\
\text { Square }\end{array}$ & $\begin{array}{l}\text { Std. Error of the } \\
\text { Estimate }\end{array}$ \\
\hline$\overline{1}$ & $.641^{a}$ & .411 & .405 & 2.725 \\
\hline
\end{tabular}

Based on the test results obtained a determination value of 0.411 means that promotion has an influence contribution of $41.1 \%$ on consumer buying interest.

Table 7.

Test Results Determination Coefficient Accuracy of Distribution of Consumer Buying Interest. Model Summary

\begin{tabular}{lrr|rr|r}
\hline Model & & \multicolumn{2}{c|}{$\begin{array}{c}\text { Adjusted R } \\
\text { Square }\end{array}$} & $\begin{array}{c}\text { Std. Error of the } \\
\text { Estimate }\end{array}$ \\
\hline 1 & $\mathrm{R}$ & \multicolumn{1}{c|}{ R Square } & .391 & .385 & 2.771 \\
\hline
\end{tabular}

a. Predictors: (Constant), Distribution Accuracy (X2)

Based on the test results obtained a determination value of 0.391 means that the accuracy of distribution has an influence contribution of $39.1 \%$ on consumer buying interest.

Table 8.

Test Results for Promotion Determination Coefficient and Accuracy of Distribution of Consumer Buying Interest.

Model Summary

\begin{tabular}{|c|c|c|c|c|}
\hline Model & $\mathrm{R}$ & R Square & $\begin{array}{c}\text { Adjusted R } \\
\text { Square }\end{array}$ & $\begin{array}{l}\text { Std. Error of the } \\
\text { Estimate }\end{array}$ \\
\hline 1 & $.709^{a}$ & .502 & .492 & 2.519 \\
\hline
\end{tabular}

a. Predictors: (Constant), Distribution Accuracy (X2), Promotion (X1) 
Based on the test results obtained a determination value of 0.502 means that promotion and accuracy of the distribution simultaneously have an influence contribution of $50.2 \%$ on consumer buying interest, while the remaining $49.8 \%$ is influenced by other factors.

\section{Hypotesis Testing}

Table 9

Hypothesis testing with a t-test is used to find out which partial hypotheses are accepted.

Promotion Hypothesis Test Results Against Consumer Buying Interest.

\section{Coefficients $^{\mathrm{a}}$}

\begin{tabular}{|c|c|c|c|c|c|c|}
\hline \multirow{2}{*}{\multicolumn{2}{|c|}{ Model }} & \multicolumn{2}{|c|}{$\begin{array}{c}\text { Unstandardized } \\
\text { Coefficients }\end{array}$} & \multirow{2}{*}{$\begin{array}{c}\text { Standardized } \\
\text { Coefficients } \\
\text { Beta }\end{array}$} & \multirow[b]{2}{*}{$\mathrm{t}$} & \multirow[b]{2}{*}{ Sig. } \\
\hline & & $\mathrm{B}$ & Std. Error & & & \\
\hline \multirow[t]{2}{*}{1} & (Constant) & 16.434 & 2.815 & & 5.837 & .000 \\
\hline & Promotion (X1) & .592 & .073 & .641 & 8.103 & .000 \\
\hline
\end{tabular}

a. Dependent Variable: Increased Sales (Y)

Based on the test results in the above table, the value of $t_{\text {count }}>t_{\text {table }}$ or $(8,103>1,661)$ is obtained, thus the first hypothesis proposed that there is a significant influence on the promotion of consumer buying interest is accepted.

Table 10.

Hypothesis Test Results Appropriate Distribution of Consumer Buying Interest.

Coefficients $^{\mathrm{a}}$

\begin{tabular}{|c|c|c|c|c|c|}
\hline \multirow[b]{2}{*}{ Model } & \multicolumn{2}{|c|}{$\begin{array}{l}\text { Unstandardized } \\
\text { Coefficients }\end{array}$} & \multirow{2}{*}{$\begin{array}{c}\text { Standardized } \\
\text { Coefficients } \\
\text { Beta } \\
\end{array}$} & \multirow[b]{2}{*}{$\mathrm{t}$} & \multirow[b]{2}{*}{ Sig. } \\
\hline & B & Std. Error & & & \\
\hline (Constant) & 16.371 & 2.944 & & 5.561 & .000 \\
\hline Distribution Accuracy (X2) & .594 & .076 & .625 & 7.769 & .000 \\
\hline
\end{tabular}

a. Dependent Variable: Increased Sales (Y)

Based on the test results in the above table, the value of $t_{\text {count }}>t_{\text {table }}$ or $(7,769>1,661)$ is obtained, thus the second hypothesis proposed that there is a significant influence between the accuracy of the distribution on consumer buying interest is accepted.

Hypothesis testing with the F test is used to find out which simultaneous hypotheses are accepted.

Table 11.

Promotion Hypothesis Test Results and Appropriate Distribution of Consumer Buying Interests.

ANOVA $^{\mathrm{a}}$

\begin{tabular}{llr|r|r|c|c}
\hline \multicolumn{1}{c}{ Model } & Sum of Squares & \multicolumn{1}{c}{ df } & Mean Square & \multicolumn{1}{c}{ F } & \multicolumn{1}{c}{ Sig. } \\
\hline 1 & Regression & 595.336 & 2 & 297.668 & 46.928 & $.000^{\mathrm{b}}$ \\
\cline { 2 - 7 } & & & & & \\
\hline Residual & 589.904 & 93 & 6.343 & & \\
\hline Total & 1185.240 & 95 & & & \\
\hline
\end{tabular}

a. Dependent Variable: Increased Sales (Y)

b. Predictors: (Constant), Distribution Accuracy (X2), Promotion (X1) 
Based on the test results in the table 11 , the value of $F_{\text {count }}>F_{\text {table }}$ or $(46.928>2,700)$ is obtained, thus the third hypothesis proposed that there is a significant influence between promotion and accuracy of distribution on consumer buying interest is accepted.

\section{CONCLUSION}

The promotion has a significant effect on consumer buying interest with an influence contribution of $41.1 \%$. Hypothesis testing obtained value of $t_{\text {count }}>t_{\text {table }}$ or $(8,103>1,661)$. The accuracy of the distribution has a significant effect on consumer buying interest with a contribution of $39.1 \%$. Hypothesis testing obtained $t_{\text {count }}>t_{\text {table }}$ or $(7.769>1.661)$. Promotion and accuracy of distribution have a significant effect on consumer buying interest with a contribution of $50.2 \%$ while the remaining $49.8 \%$ is influenced by other factors. Hypothesis testing obtained the value of $F_{\text {count }}>F_{\text {table }}$ or $(46.928>2.700)$.

\section{REFERENCES}

Alma, B. (2011). Pemasaran dan Pemasaran Jasa. In Pemasaran dan Pemasaran Jasa.

Angipora, M. P. (2002). Dasar-Dasar Pemasaran. Manajemen Pemasaran,Dasar-dasar pemasaran / Marius P. Angipora. https://doi.org/2002

Assauri, S. (2011). Manajemen Pemasaran Dasar Konsep dan Strategi. In PT RajaGrafindo Persada, Jakarta. https://doi.org/10.1109/ACC.2007.4282338

Fandy Tjiptono dan Gregorius Chandra. (2008). Pemasaran Strategi. Andi Office.

Kotler dan Amstrong. (2008). Prinsip-Prinsip Pemasaran Jilid I. In Erlangga.

Kotler, P., \& Keller, K. L. (2009). Manajemen pemasaran Jilid 1. In Jakarta.

Lovelock, Wirtz, M. (2013). Pemasaran jasa. Journal of Chemical Information and Modeling. https://doi.org/10.1017/CBO9781107415324.004

Lupiyoadi. (2011). Manajemen Pemasaran Jasa Teori dan Praktik. In Salemba Empat. https://doi.org/10.1002/cb.84

Lupiyoadi, R. (2013). Manajemen Pemasaran Jasa: Berbasis Kompetensi Edisi 3. Penerbit Salemba.

Maruf, H. (2006). Pemasaran Ritel. In Jakarta: Gramedia Pustaka Utama. https://doi.org/10.1007/s10872-006-0051-9

Morissan. (2015). Periklanan: Komunikasi Pemasaran Terpadu. Jakarta: Prenada Media Group.

Peter, J. P., \& Olson, J. C. (2014). Perilaku Konsumen dan Strategi Pemasaran. In salemba empat.

Schiffman, L., \& Kanuk, L. L. (2008). Perilaku konsumen. Jakarta: Indeks.

Shinta, A. (2011). Manajemen Pemasaran (terjemahan). In Edisi Millenium, Jilid 1.

Sumarwan, U. (2014). Model Keputusan Konsumen. Perilaku konsumen. 
Volume 3, Issue 2, March, 2020 Page. 119- 126

Sutisna. (2003). Perilaku Konsumen: Teori dan penerapannya dalam Pemasaran. Ghalia Indonesia, Jakarta. https://doi.org/10.1007/BF01013984

Swastha, Basu, I. (2014). Manajemen Pemasaran Modern. In Liberty, Yogyakarta. https://doi.org/10.1017/CBO9781107415324.004

Tulasi, D. (2012). Komunikasi Pemasaran. Humaniora. 